\title{
A comparative study on the extraction effects of common agents on collagen-based binders in mural paintings
}

\author{
Jianghao Du' ${ }^{1}$ Zhanyun Zhu ${ }^{2^{*}}$ (1), Junchang Yang ${ }^{1,3^{*}}$, Jia Wang ${ }^{2}$ and Xiaotong Jiang ${ }^{2}$
}

\begin{abstract}
In this paper, a comparative study was conducted on the extraction effects of six agents for collagen-based mural painting binders. These agents were used to extract the residual proteins in the non-aged and thermal aged samples. The protein extraction efficiencies of different extracting agents were quantitatively determined by bicinchoninic acid (BCA) method, and then processed by multivariate analysis of variance (MANOVA). The impact of the extraction process on the protein structure was characterized by sodium dodecyl sulfate polyacrylamide gel electrophoresis (SDSPAGE), ultraviolet absorption spectrum (UV) and circular dichroism (CD). The results showed that, for both non-aged and aged samples, the extraction efficiency of $2 \mathrm{M}$ guanidine hydrochloride (GuHCl) was significantly higher than the other five agents, with less damage to the protein structure during the extraction process.
\end{abstract}

Keywords: Mural painting binders, BCA method, Protein extraction, GuHCl solution, MANOVA

\section{Introduction}

Protecting cultural heritage is an important calling to ensure that future generations have the opportunity to appreciate them [1]. As an essential part of cultural heritage and a treasure of human civilization, mural paintings can reflect the characteristics of religion, society, clothing, architecture and other aspects of the corresponding historical period [2]. Since the materials and production techniques of murals are closely related to the specific regions and periods, scientific examination of mural paintings can provide valuable information on art, culture, science and technology.

In composition, paint is formed by dispersing pigments in binders, so that binding media can hold individual powder particles together and attach them to the

\footnotetext{
*Correspondence: zhanyun.zhu@xmu.edu.cn; yangjunchang@nwpu.edu.cn ${ }^{1}$ Center for Nano Energy Materials, State Key Laboratory of Solidification Processing, School of Materials Science and Engineering, Northwestern Polytechnical University, Xi'an 710072, China

${ }^{2}$ Conservation Science Laboratory, Department of History, College of Humanities, Xiamen University, Xiamen 361005, China

Full list of author information is available at the end of the article
}

base layers $[3,4]$, determining the optical and mechanical properties of the paint [5]. In addition to playing an important role in food [6-8] and medicine [9], collagen is also one of the most important materials for making mural painting binders [10]. Specifically, these binders are predominantly gelatin, which is the soluble state of collagen through the extraction from the source material, heat, or a combination of the two factors. They are likely a rich mixture of collagen-based peptides in a variety of structural states ranging from partially unfolded triple helices to random coils. Hence, accurate identification of proteinaceous degradation residues in ancient mural paintings could reveal the original types of binders, and then the rich cultural, technical and social connotations could be explored. It can not only show the craftsmanship of mural paintings, but also guide their restoration, storage and display.

There are three common methods for protein identification, including proteomics [11-16], immunology [1719], and amino acid analysis (AAA) [20, 21]. It should be emphasized that extracting target proteins from paint matrix is a prerequisite for all these identification 
approaches. As binding media in ancient paintings are prone to degradation and contamination, they are difficult to be extracted, which poses a great challenge to identification. Therefore, it is expected that optimizing the extraction methodology for mural painting binders could effectively improve the success rate and accuracy of identification, and then minimize sampling area of ancient mural paintings.

Reagents routinely used to extract proteinaceous residues from paint samples include trifluoroacetic acid (TFA) [14, 22, 23], Urea [5, 24, 25], guanidine hydrochloride $(\mathrm{GuHCl})[26,27]$, ammonia [14, 28, 29] and ammonium bicarbonate (AMBIC) [30-32]. Acetic acid is also a potential candidate, as it is commonly used for biological collagen extraction [33, 34], paleontology [35, 36] and food industry [37]. At present, most studies focused on the optimization of post-extraction identification methods [31, 38-40], or aimed at enriching the sequence database [41]. Additionally, previous studies on the optimization of protein extraction process mainly compared the extraction efficiency of different extraction agents through the results of mass spectrometry, and the research objects were egg albumin [14] and food residue proteins [42] instead of collagen/gelatin.

In this paper, the extraction efficiency of different agents and possible changes in molecular structure of extracted protein were studied directly after extraction. Samples were made by mixing $\mathrm{Fe}_{2} \mathrm{O}_{3}$ pigment with four respective animal glues that were commonly used as binders in historical paintings [5, 43-45]. As a routine way of artificial aging for paint binders [46-48], the samples were thermally aged, then subjected to different extracting agents. BCA method was used for quantitative analysis of extraction efficiency, and sodium dodecyl sulfate polyacrylamide gel electrophoresis (SDS-PAGE), ultraviolet absorption spectrum (UV) and circular dichroism $(C D)$ were used to characterize the influence of extraction process on the structure of protein, so as to determine the most suitable extracting agent for collagen-based binders in mural painting.

\section{Materials and methods Materials}

Bovine bone glue (No. 63000), cowhide glue (No. 63020), rabbit skin glue (No. 63028) and bookbinder glue (No. 63060) were purchased from Kremer (Germany). $\mathrm{Fe}_{2} \mathrm{O}_{3}$ powder was provided by FUCHEN (China). Tetramethylethylenediamine (TEMED), Urea, GuHCl, AMBIC, TFA, ammonia, sodium dihydrogen phosphate $\left(\mathrm{NaH}_{2} \mathrm{PO}_{4}\right)$, dibasic sodium phosphate $\left(\mathrm{Na}_{2} \mathrm{HPO}_{4}\right)$, sodium tartrate, Bicinchonic acid disodium salt, sodium dodecyl sulfate (SDS) and ammonium persulfate were purchased from Sigma-Aldrich (USA). Methanol, ethanol, acetic acid, phosphoric acid, sodium hydroxide, sodium bicarbonate, anhydrous sodium carbonate and copper sulfate pentahydrate were purchased from Tianli (China). Coomassie brilliant blue G-250, Bovine Serum Albumin (BSA), collagen I, protein marker (43-200 kDa), loading buffer, Tris-Glycine running buffer, $30 \%$ acrylamide solution, $1 \mathrm{M}$ Tris $\mathrm{HCl}(\mathrm{pH}=6.8)$ and $1.5 \mathrm{M}$ Tris $\mathrm{HCl}(\mathrm{pH}=8.8)$ were supplied by Solarbio (China).

\section{Sample preparation \\ Non-aged samples}

The above four kinds of animal glue were fully dissolved in deionized water using a vortex (QL-901, Kylin-Bell) at $40{ }^{\circ} \mathrm{C}$ respectively, prepared into solutions of $30 \mathrm{mg} / \mathrm{mL}$ concentration. After cooling to room temperature, the solutions were centrifuged (by 3K15, SIGMA, at $5000 \mathrm{r} /$ $\mathrm{min}, 10 \mathrm{~min}, 20{ }^{\circ} \mathrm{C}$ ). Then the supernatants were completely mixed with $\mathrm{Fe}_{2} \mathrm{O}_{3}$ powder (a regularly used pigment in mural paintings $[49,50])$, and the weight ratio of solute in the solution and pigments was about 1:2. Aliquots of $100 \mu \mathrm{L}$ mixture were transferred onto glass slides, and placed in darkness at room temperature for 6 months to obtain non-aged samples.

\section{Aged samples}

The six aged samples were obtained by placing the samples prepared with rabbit skin glue into a circularly air oven (DHG-9030a, Huitai) at $100{ }^{\circ} \mathrm{C}$ for $0,300,600,1000$, 1500 and $2000 \mathrm{~h}$. Based on previous studies [51-53], the thermal degradation process of binders should follow Arrhenius Equation:

$$
\mathrm{k}=\mathrm{A} \exp \left(\frac{-E}{R T}\right)
$$

wherein $\mathrm{E}$ is the activation energy, $\mathrm{A}$ is the pre-factor, $\mathrm{R}$ is the gas constant, and $\mathrm{T}$ is the absolute temperature. At any aging temperature $(t)$ higher than room temperature $\left(25^{\circ} \mathrm{C}\right)$, the accelerating factor $\mathrm{F}$ would be:

$$
\mathrm{F}=\frac{k_{t}}{k_{25^{\circ} \mathrm{C}}}
$$

Therefore:

$$
\mathrm{F}=\exp \left(-\frac{E}{R}\left(\frac{1}{t}-\frac{1}{298}\right)\right)
$$

wherein $\mathrm{E}$ could be derived from previous research on degradation process of gelatin to be around $85 \mathrm{~kJ} / \mathrm{mol}$ $[54,55], \mathrm{t}$ in this paper is $100{ }^{\circ} \mathrm{C}$. According to the above theoretical calculation, samples aged at $100{ }^{\circ} \mathrm{C}$ for $2000 \mathrm{~h}$ were comparable to approximately 225 years at room temperature. Considering the impact of inorganic pigment, the actual aging equivalent would be longer. The 
sample composition and treatment conditions are shown in Table 1.

\section{Protein extraction}

Six commonly used extraction agents for animal glue were selected: $0.1 \%$ TFA, $2 \mathrm{M} \mathrm{GuHCl}, 2 \mathrm{M}$ Urea, $0.5 \mathrm{M}$ Acetic acid, $2 \mathrm{M}$ ammonia and $0.1 \mathrm{M}$ AMBIC. Samples were separated from slides and mixed with $300 \mu \mathrm{L}$ of each extraction agent, deionized water was also mixed with samples as control. The mixtures were subjected to 15 min ultrasonic treatment, then heated at $60{ }^{\circ} \mathrm{C}$ for $2 \mathrm{~h}$, followed by another ultrasonic treatment for $45 \mathrm{~min}$. After cooling to room temperature and centrifugation (15 min, $20{ }^{\circ} \mathrm{C}, 5000 \mathrm{r} / \mathrm{min}$ ), the supernatants were used in the following steps.

\section{Quantitative determination of protein concentration}

The principle of BCA-Cu method is that $\mathrm{Cu}^{2+}$ can be reduced by protein to $\mathrm{Cu}^{+}$, forming a purple complex with bicinchoninic acid under alkaline condition. After the reaction, change in absorbance reaches maximum at $562 \mathrm{~nm}$, showing a linear relationship with protein concentration in a certain range. BCA method proposed by Smith et al. [56] was optimized. To elucidate possible influence of different standard proteins and solvents, BSA and collagen I were used as standard proteins for comparison, and respective standard curves were plotted with each extraction agents. The extracted supernatants were diluted with $1 \times$ PBS, reaching 10 times of the original volume. $\mathrm{BCA}$ reagent and $\mathrm{Cu}$ reagent were blended into BCA working solution at a volume ratio of 50:1. The BCA working solution and the diluted solutions were mixed at a volume ratio of $10: 1$ and heated at $37{ }^{\circ} \mathrm{C}$ for $30 \mathrm{~min}$. After chilling to room temperature, a microultraviolet spectrophotometer (DS-11, Denovix) was utilized to quantitatively determine the protein concentration. Each experiment was repeated in triplicate.

\section{Statistical analysis}

Multivariate analysis of variance (MANOVA) was employed to statistically analyze and calculate the effects of extracting agent type, animal glue type and aging time on extraction efficiency. SPSS 25 (IBM) was used and 95\% confidence interval $(\mathrm{p}<0.05)$ was set.

\section{Microstructural analysis \\ Sodium dodecyl sulfate polyacrylamide gel electrophoresis (SDS-PAGE)}

According to Laemmli's method [57], SDS-PAGE was used to characterize the purity and molecular weight of the extracted proteins. The extracted protein solutions $(40 \mu \mathrm{L})$ and loading buffer $(10 \mu \mathrm{L})$ were thoroughly mixed and heated at $100{ }^{\circ} \mathrm{C}$ for $10 \mathrm{~min}$. After reaching room temperature, the mixtures were centrifugated $(13,000 \mathrm{r} /$ min, $3 \mathrm{~min}$ ). $10 \mathrm{~mL}$ of supernatants and $6 \mu \mathrm{L}$ protein marker were used for electrophoresis under constant voltage, which was $100 \mathrm{~V}$ in the range of stacking gel (5\%) and $150 \mathrm{~V}$ in the range of resolving glue (7\%). The gels were stained with Coomassie brilliant blue G-250 for $4 \mathrm{~h}$, then destained for $5 \mathrm{~h}$.

\section{Ultraviolet spectroscopy (UV)}

Ultraviolet spectrophotometer (DS-11, Denovix) was applied to test the extracted supernatants with a spectral scan range of 200-400 $\mathrm{nm}$. The optical path length in the transmission measurements was $10 \mathrm{~mm}$. Each extraction agent was employed as baseline for the corresponding protein solution.

\section{Circular dichroism (CD)}

Circular dichrograph (ChirascanV100, Applied Photophysics, UK) was used to perform circular dichroism test on the supernatant. Three scans were averaged in a wavelength range from 190 to $260 \mathrm{~nm}$ at $25{ }^{\circ} \mathrm{C}$. Each

Table 1 Composition and treatment conditions of samples

\begin{tabular}{|c|c|c|c|c|c|}
\hline Type & Sample No & Composition & Source & Method & Time \\
\hline \multirow[t]{4}{*}{ Non-aged samples } & NAg-1 & Bovine bone glue $+\mathrm{Fe}_{2} \mathrm{O}_{3}$ powders & NO.63000, Kremer & $25^{\circ} \mathrm{C}, \mathrm{RH} 40 \%$ & 6 months \\
\hline & $\mathrm{NAg}-2$ & Cowhide glue $+\mathrm{Fe}_{2} \mathrm{O}_{3}$ powders & NO.63020, Kremer & & \\
\hline & $\mathrm{NAg}-3$ & Rabbit skin glue $+\mathrm{Fe}_{2} \mathrm{O}_{3}$ powders & NO.63028, Kremer & & \\
\hline & $\mathrm{NAg}-4$ & Bookbinder glue $+\mathrm{Fe}_{2} \mathrm{O}_{3}$ powders & NO.63060, Kremer & & \\
\hline \multirow[t]{6}{*}{ Aged samples } & $\mathrm{Ag}-0$ & Rabbit skin glue $+\mathrm{Fe}_{2} \mathrm{O}_{3}$ powders & NO.63028, Kremer & After 6 months, $100{ }^{\circ} \mathrm{C}$ & $\mathrm{Oh}$ \\
\hline & $\mathrm{Ag}-1$ & & & & $300 \mathrm{~h}$ \\
\hline & $\mathrm{Ag}-2$ & & & & $600 \mathrm{~h}$ \\
\hline & $\mathrm{Ag}-3$ & & & & $1000 \mathrm{~h}$ \\
\hline & $\mathrm{Ag}-4$ & & & & $1500 \mathrm{~h}$ \\
\hline & $\mathrm{Ag}-5$ & & & & $2000 \mathrm{~h}$ \\
\hline
\end{tabular}


extraction agent was used as baseline for the corresponding protein solution.

\section{Results and discussions}

In theory, when making standard curve in colorimetric method, specific proteins and solvents should be adopted according to the corresponding sample compositions [58-60]. In some cases, though, a single standard curve was constructed for BCA testing on different protein solutions [61-63]. As for collagen and multiple extracting agents, this approach may affect the accuracy of protein concentration test. Therefore, the possible influence of different standard proteins and extraction agents on experimental results should first be explored.

As shown in Fig. 1, the absorbance of collagen I at $562 \mathrm{~nm}$ is remarkably lower than BSA at the same concentration, consistent with Duhamel et al. [58]. Proteins react with $\mathrm{BCA}$ working solution via reducing amino acids such as tryptophan and tyrosine. In collagen I, there is no tryptophan, and tyrosines are restricted to telopeptides that could possibly be lost during the

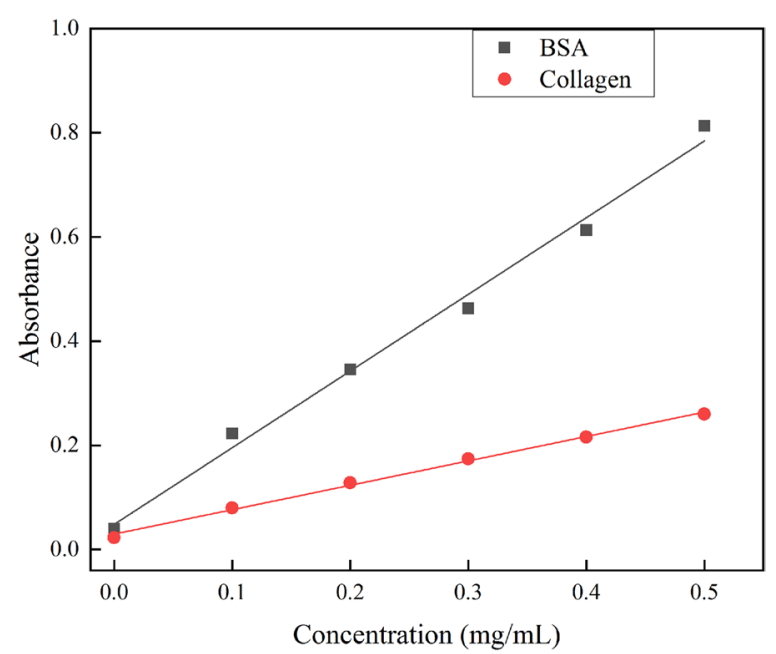

Fig. 1 Comparison of absorbance between collagen and BSA at $562 \mathrm{~nm}$ extraction. As the amount of these amino acids in collagen are evidently less than in BSA, the absorbance of BSA varies more at different concentrations. As the objective of this study is to compare the extraction efficiency of each agent, plotting the standard curve using BSA could make the results more comparable with previous studies $[17,64]$, without changing the order and gradient of the outcome. Therefore, BSA standard was adopted below.

In order to minimize the interference of different extraction agents on the BCA results, each standard curve should be constructed for corresponding agents. However, the sensitivity and accuracy would be enormously affected by ammonia [65], urea and $\mathrm{GuHCl}$ at high concentration [64]. Therefore, dilution of the extracted protein solution 10 times with $1 \times$ PBS was attempted, no precipitation occurred, and the BSA solutions for constructing standard curves were prepared accordingly. The specific components are shown in Table 2. At each concentration of BSA solution, extracting agents accounted for $10 \%$ of the total volume, which was the same as the protein solution obtained by diluting the supernatant with $1 \times$ PBS. As shown in Fig. 2, the linear fitting slope of each curve was relatively close, indicating the interference of the extraction agents to the BCA reaction is nearly eliminated after 10 times of dilution. The slope of control was 1.919 , while that of $2 \mathrm{M}$ ammonia was the highest (2.031), suggesting the change of absorbance was related to the $\mathrm{pH}$ of solution [66]. The slope of $2 \mathrm{M}$ Urea was the lowest (1.731) because the presence of urea reduces the absorbance of the BCA reaction, consistent with Walker et al. [67].

The efficiencies of different agents were quantitatively compared using the following approach. The original concentration of animal glue was $30 \mu \mathrm{g} / \mu \mathrm{L}$, and the total volume of glue added to each sample was $100 \mu \mathrm{L}$, making the mass $\mathrm{p}$ of animal glue contained in each sample $3000 \mu \mathrm{g}(30 \times 100)$. The volume of extraction agents for each sample was $300 \mu \mathrm{L}$, the dilution ratio of

Table 2 Components of BSA solution at various concentrations for each agent

\begin{tabular}{|c|c|c|c|}
\hline \multirow{2}{*}{$\begin{array}{l}\text { Concentration of BSA solution }(\mathrm{mg} / \\
\mathrm{mL})\end{array}$} & \multicolumn{3}{|c|}{ composition and volume $(\mu \mathrm{L})$} \\
\hline & 100 & 100 & 800 \\
\hline 0 & $1 \times \mathrm{PBS}$ & Extraction agents $(1 \times$ PBS as control) & $1 \times \mathrm{PBS}$ \\
\hline 0.1 & $1 \mathrm{mg} / \mathrm{mL} \mathrm{BSA}$ in $1 \times \mathrm{PBS}$ & & \\
\hline 0.2 & $2 \mathrm{mg} / \mathrm{mL} \mathrm{BSA}$ in $1 \times \mathrm{PBS}$ & & \\
\hline 0.3 & $3 \mathrm{mg} / \mathrm{mL}$ BSA in $1 \times \mathrm{PBS}$ & & \\
\hline 0.4 & $4 \mathrm{mg} / \mathrm{mL} \mathrm{BSA}$ in $1 \times \mathrm{PBS}$ & & \\
\hline 0.5 & $5 \mathrm{mg} / \mathrm{mL}$ BSA in $1 \times$ PBS & & \\
\hline
\end{tabular}




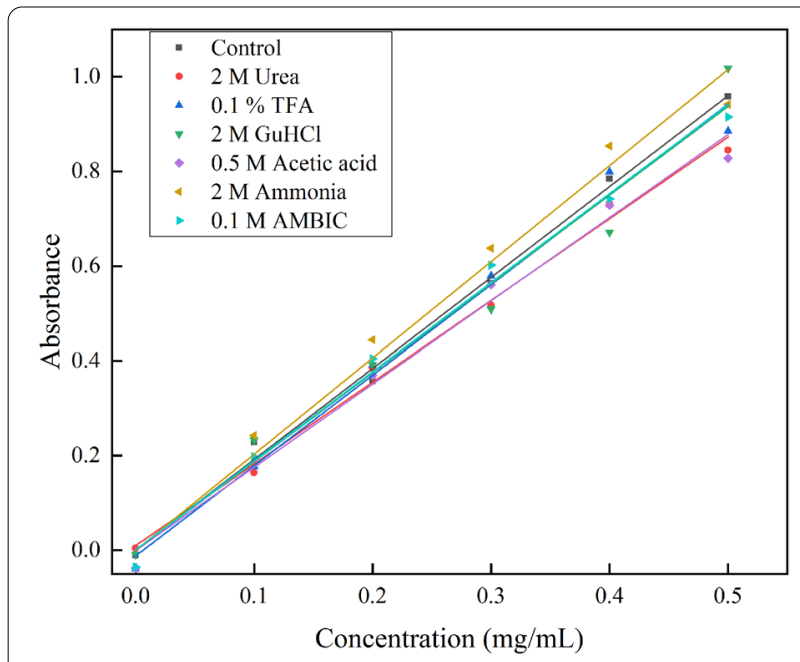

Fig. 2 BCA standard curves of different extraction agents as solvent component (BSA as standard protein)

$1 \times$ PBS was 10 , and the final protein concentration was $\mathrm{y} \mu \mathrm{g} / \mu \mathrm{L}$. Thus, the total mass q of the extracted protein in each sample was 3000y $\mu \mathrm{g}(10 \times 300 \times \mathrm{y})$.

Make extraction efficiency be $\eta$ :

$$
\eta=\frac{q}{p} \times 100 \%=\frac{3000 \mathrm{y}}{3000} \times 100 \%=\mathrm{y}
$$

The extraction efficiency of each extracting agent for non-aged samples is illustrated in Fig. 3. The results show that the highest extraction efficiency of the non-aged sample was $38.1 \%$ (NAg-3 extracted by $2 \mathrm{M}$ $\mathrm{GuHCl}$ ), and the lowest was $25.4 \%$ (NAg-1 extracted by
$2 \mathrm{M}$ ammonia). From the result of MANOVA (shown in Additional file 1: Table S1), the order of extraction efficiency $\eta$ for different agents was: $2 \mathrm{M} \mathrm{GuHCl}>0.5 \mathrm{M}$ acetic acid, $2 \mathrm{M}$ urea $>0.1 \%$ TFA $>0.1 \mathrm{M}$ AMBIC $>2 \mathrm{M}$ ammonia, control $(\mathrm{p}<0.05)$.

Unexpectedly, the difference of extraction efficiency between $2 \mathrm{M}$ ammonia and control was not significant $(p>0.05)$, while the extraction efficiencies of other agents were remarkably higher $(\mathrm{p}<0.05)$. The variation of binder type had no evident effect on the extraction efficiency $(\mathrm{p}>0.05)$, as the main ingredients and production techniques of bovine bone glue (NAg-1), cowhide glue (NAg-2, NAg-4) and rabbit skin glue (NAg-3) are similar, meaning that the polymorphism of collagen caused by species difference had no effect on the results [68]. Therefore, rabbit skin glue (NAg-3) was used in follow-up thermal aging experiment.

In Fig. 4, the extraction efficiencies of different extracting agents for increasingly aged samples were depicted. From the results of MANOVA (see Additional file 1: Table S2), the order of the extraction efficiency $\eta$ for different agents was: $2 \mathrm{M} \mathrm{GuHCl}>0.5 \mathrm{M}$ acetic acid, $2 \mathrm{M}$ urea, $0.1 \%$ TFA, $0.1 \mathrm{M}$ AMBIC $>2 \mathrm{M}$ ammonia $>$ control $(\mathrm{p}<0.05)$.

The extraction efficiency of $2 \mathrm{M} \mathrm{GuHCl}$ was significantly higher than other agents $(\mathrm{p}<0.05)$, and the efficiencies of all six agents were significantly higher than control $(p<0.05)$. There was no visible difference in extraction efficiencies among $0.5 \mathrm{M}$ acetic acid, $2 \mathrm{M}$ urea, $0.1 \%$ TFA and 0.1 M AMBIC ( $p>0.05)$. The effect of aging time on the extraction efficiency was: Nonaged $>300 \mathrm{~h}>600 \mathrm{~h}>1000 \mathrm{~h}>1500 \mathrm{~h}>2000 \mathrm{~h}(\mathrm{p}<0.05)$.

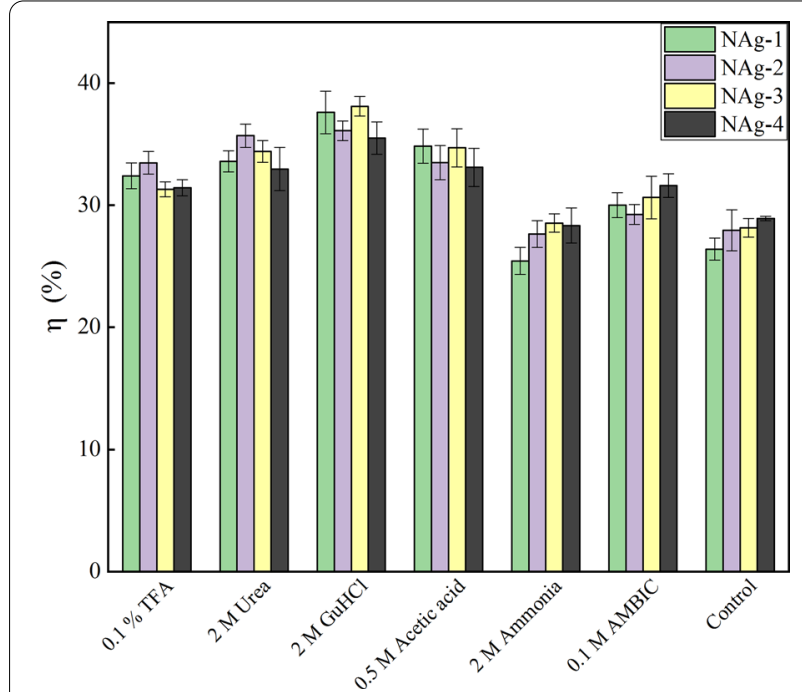

Fig. 3 Extraction efficiency $\eta$ of protein in non-aged samples with different extraction agents

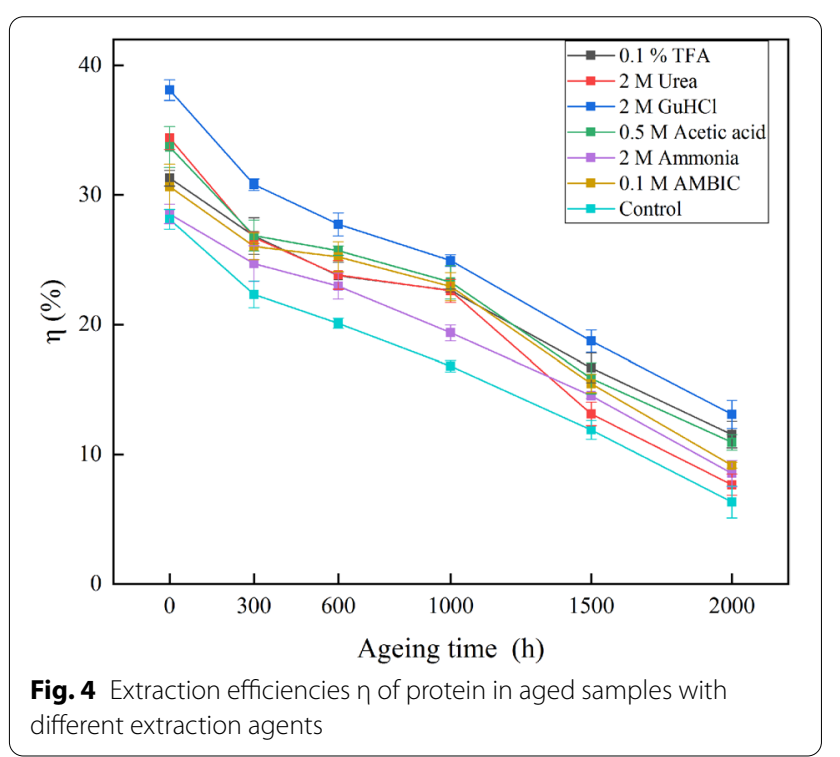


The protein extraction efficiencies of the long-term aged samples were significantly lower than the shortterm aged ones. Specifically, for the non-aged samples, the extraction efficiency of each agent was in the range of $28.1-38.1 \%$, while it was $16.8-24.9 \%$ for $1000 \mathrm{~h}$ aged samples, and $6.3-13.1 \%$ for $2000 \mathrm{~h}$ aged ones. This phenomenon indicated that the protein in the glue was pretty much denatured after thermal treatment, contributing to the lower extraction efficiency.

The chemistry resulting from heating is complex, with both bond scission and formation effects. The presence of pigment could also accelerate the protein denaturation process. For example, interaction with $\mathrm{Fe}_{2} \mathrm{O}_{3}$ could bring about an increase in random coil [69], and involvement of iron in metal-polypeptide coordination could force the protein into a conformation more easily degraded by thermal process [70]. With the effect of both heating and inorganic pigment, the secondary structure, tertiary structure and quaternary structure of protein in the aged samples were altered, inducing aggregation maintained by electrostatic interaction and hydrophobic bond [71]. Along with molecular chain unfolding, some functional groups enclosed before the thermal treatment were exposed, including chromophores such as $\mathrm{C}=\mathrm{O}$, $\mathrm{COOH},-\mathrm{CONH}_{2}$, and low content of benzene ring, as there are only $1 \%$ tyrosine, $2-3 \%$ phenylalanine, and no tryptophan in gelatin [72]. As a result, the molecular surface activity was enhanced, and the formation of interand intra-molecular cross-links was promoted [73]. Hence, a large number of hydrogen bonds were formed to stabilize the crosslinked structure [74], Schiff bases were also produced between amino groups and carboxylic acids [75]. In general, the level of bond breaking in protein was surpassed by the level of bond formation, fostering aggregation and cross-link [76], leading to higher insolubility of protein and lower extraction efficiencies.

From the data in Fig. 4, the analysis and comparison of the extraction efficiencies of extraction agents under longer aging times would better represent the case of ancient paint samples. Hence, MANOVA was performed on the three groups with aging time of $1000 \mathrm{~h}, 1500 \mathrm{~h}$ and $2000 \mathrm{~h}$ (shown in Additional file 1: Table S3), and the order of extraction efficiencies was: $2 \mathrm{M} \mathrm{GuHCl}>0.5 \mathrm{M}$ acetic acid, 0.1\% TFA $>0.1 \mathrm{M}$ AMBIC $>2 \mathrm{M}$ Urea, $2 \mathrm{M}$ ammonia $>$ control $(\mathrm{p}<0.05)$.

For longer ageing times, the extraction efficiencies of $0.5 \mathrm{M}$ acetic acid, $0.1 \%$ TFA, $0.1 \mathrm{M}$ AMBIC and $2 \mathrm{M}$ urea were markedly different, and the extraction efficiency of $2 \mathrm{M}$ urea was remarkably reduced. In addition to the effect on inter- and intra-molecular hydrogen bonds, urea has a strong affinity for amides and peptide bonds, could thus promote the dissolution of some types of protein by destroying amide cross-linking [77]. For seriously aged samples, more deamidation may have impaired the solubilization effect of urea [27].

From the above statistical analysis, the extraction efficiency of $2 \mathrm{M} \mathrm{GuHCl}$ was significantly higher than other extraction agents for both non-aged and aged samples. Compared with other agents, $\mathrm{GuHCl}$ has a stronger solubilizing effect on hydrophobic amino acid residues by weakening the hydrophobic interactions [78, 79]. Aged samples tend to be more insoluble, owing to the growing aggregation and cross-linking. Besides destroying hydrophobic bonds, $\mathrm{GuHCl}$ could also facilitate the breakage of hydrogen bonds and shield the electrostatic effects, thus eliminate the aggregation and cross-linking [80-82].

In order to show the extraction efficiency of each agent compared with control, normalization was performed. The extraction efficiency of an agent was known to be $\eta$, while that of the control was $\eta_{0}$, then relative extraction efficiency $\eta^{*}$ would be:

$$
\eta^{*}=\frac{\eta}{\eta_{0}}
$$

It can be seen in Fig. 5 that, except for $2 \mathrm{M}$ urea, there was an upward trend for relative extraction efficiency in each group with the rise of aging time. For example, $\eta^{*}$ of $2 \mathrm{M} \mathrm{GuHCl}$ increased from 1.35 to 2.12 through thermal aging for $2000 \mathrm{~h}$. As protein denaturation became more serious through aging, the level of bond formation was higher than the level of bond breakage, resulting in more insolubility. The extracting agents took effect because of stronger solubilizing ability than control by breaking certain bonds. For example, $\mathrm{GuHCl}$ could destroy hydrogen bonds, hydrophobic bonds and electrostatic interactions.

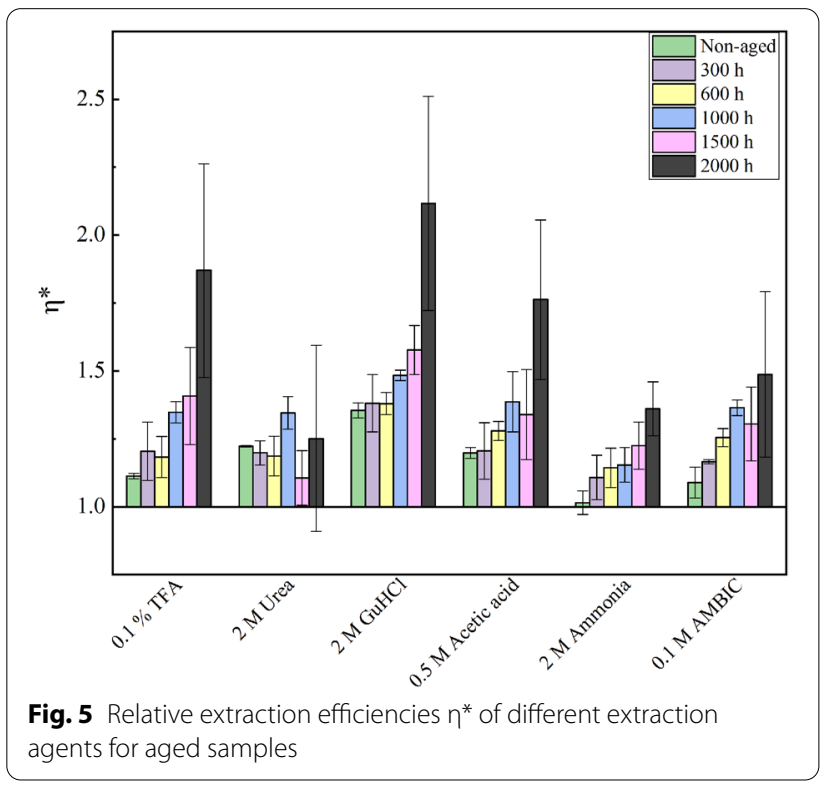


TFA, acetic acid, and ammonia could destroy the $\mathrm{pH}$ labile crosslinks, leading to the rise of $\eta^{*}[83,84]$. Some aqueous-organic systems, such as methanol and acetonitrile may also have some effects on protein extraction from non-aged samples, due to their attraction to less polar fractions in protein. However, their extraction effects on aged samples could be compromised, due to the lack of ability to eliminate crosslinks. The $\eta^{*}$ of $\mathrm{GuHCl}$ reaches 2.12 for samples aged $2000 \mathrm{~h}$, indicating that the extraction efficiency of $\mathrm{GuHCl}$ was more than doubled, compared with deionized water. It is promising that the enhancement of $\eta^{*}$ will be more significant, in the case of more denaturation and more complex preservation conditions.

As shown in Fig. 6, four obvious bands can be seen in all the lanes except lane 7 . Among them, there are three bands in the range of $97-130 \mathrm{kDa}$. From top to bottom, they should be collagen $\alpha_{1}$ chain (approximately $125 \mathrm{kDa}$ ), collagen $\alpha_{2}$ chain (approximately $115 \mathrm{kDa}$ ) [85] and rabbit muscle phosphorylase (approximately $97 \mathrm{kDa}$ ) [86]. The band slightly higher than $200 \mathrm{kDa}$ was the collagen $\beta$ chain. The pattern was the same as the result obtained by Rika Kigawa et al. [87]. The distribution of bands in lanes 2, 3, 4, 8 and 9 was not evidently different from lanes 5 and 10, indicating that all the agents except $2 \mathrm{M}$ ammonia had no remarkable effect on the purity and molecular weight of extracted proteins. It can be noted that the bands on lane 7 are

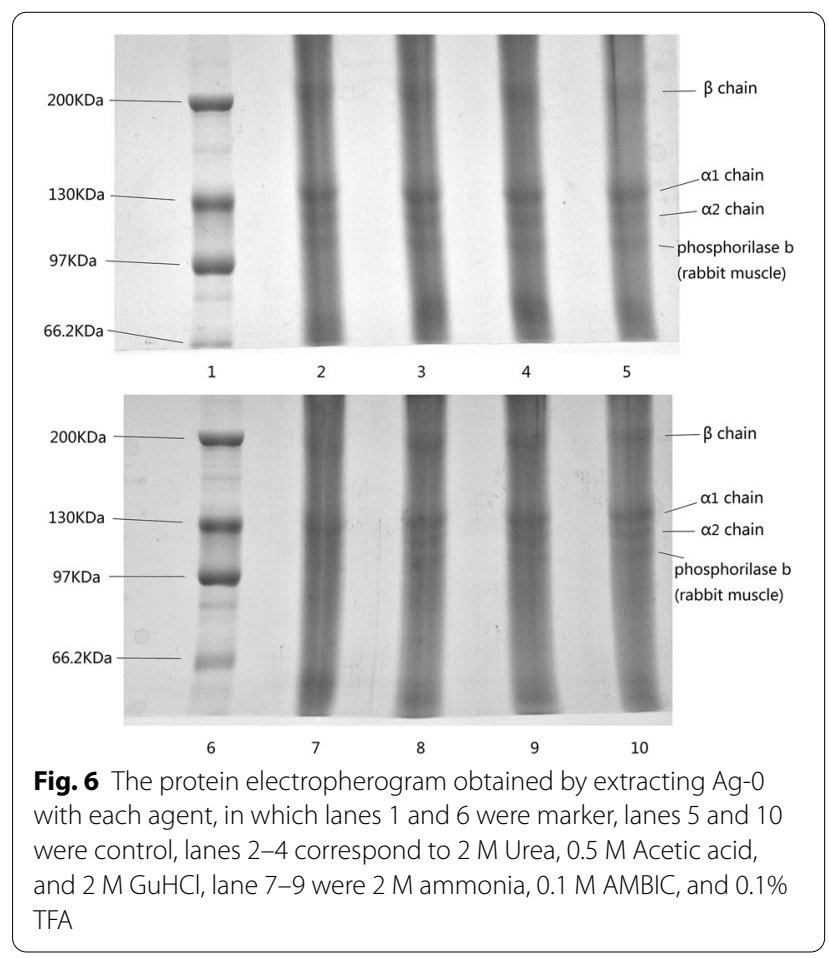

poorly resolved in comparison to those in other lanes, due to the apparent hydrolysis of proteins by $2 \mathrm{M}$ ammonia.

The UV absorption spectra of the proteins in Ag-0 extracted by each agents were shown in Fig. 7. For all the samples, there was a strong peak near $222 \mathrm{~nm}$ related to the $\mathrm{C}=\mathrm{O},-\mathrm{COOH}$, and $-\mathrm{CONH}_{2}$ groups in gelatin $[33,88,89]$, and no peak representing aromatic amino acids at $280 \mathrm{~nm}$ [90]. The peak intensities at 220-230 nm for each agent were weaker than control, suggesting that all the agents caused a certain degree of damage to the $\mathrm{C}=\mathrm{O},-\mathrm{COOH}$, and $-\mathrm{CONH}_{2}$ groups in the polypeptide chain.

In circular dichroism, natural collagen usually has an obvious negative peak in the range of $190-200 \mathrm{~nm}$, and a slight positive peak around $220 \mathrm{~nm}$ [91]. Gelatinization could unfold the protein triple helix structure into random coil, leading to the disappearance of the positive peak at $220 \mathrm{~nm}$, leaving a negative peak with reduced ellipticity $(\theta)$ at about $200 \mathrm{~nm}$ [92]. More obvious red shift of the negative peak, as well as more decrease of the peak ellipticity could imply greater extent of deconstruction in the collagenous structure. Each curve in Fig. 8 was in line with the characteristics of gelatin. The peak positions and ellipticities were shown in Table 3. Compared with control, modifications in the protein structure were revealed in the experimental groups, with alterations in the position of negative peak and ellipticity. It can be seen that $0.1 \%$ TFA, $0.5 \mathrm{M}$ acetic acid and $2 \mathrm{M} \mathrm{GuHCl}$ had slighter destructive effects on protein conformation than $2 \mathrm{M}$ urea, $2 \mathrm{M}$ ammonia and $0.1 \mathrm{M}$ AMBIC.

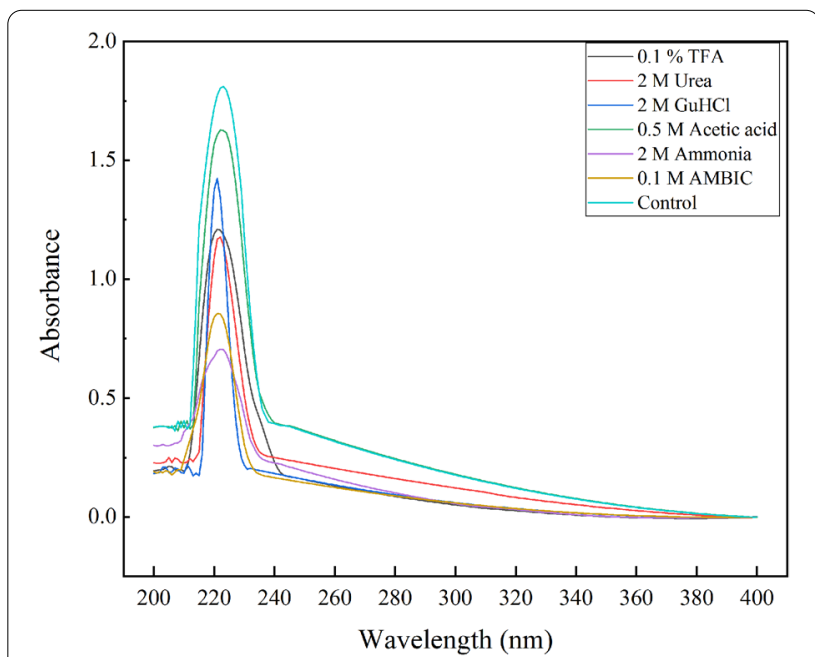

Fig. 7 UV spectra of protein extracted from Ag-0 by different extraction agents 


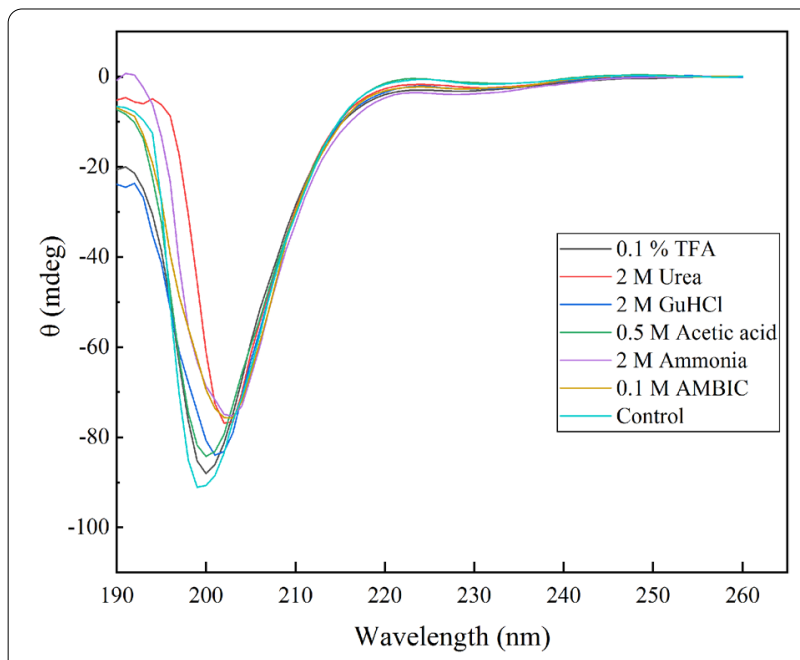

Fig. 8 CD spectra of protein extracted from Ag-0 by different extraction agents

Table 3 The position of negative peak and ellipticity of each curve in circular dichroism in Fig. 8

\begin{tabular}{lll}
\hline Agent & $\begin{array}{l}\text { Position of negative } \\
\text { peak }(\mathbf{n m})\end{array}$ & $\begin{array}{l}\text { Ellipticity } \\
\text { (mdeg) }\end{array}$ \\
\hline 0.1\% TFA & 200 & -88.02 \\
2 M urea & 202 & -76.86 \\
2 M GuHCl & 201 & -83.95 \\
0.5 M acetic acid & 200 & -84.25 \\
2 M ammonia & 203 & -75.28 \\
0.1 M AMBIC & 203 & -75.72 \\
Control & 199 & -91.12 \\
\hline
\end{tabular}

\section{Conclusion}

In this study, six commonly used extraction agents for collagen-based mural painting binder were compared and analyzed. The extraction efficiency of each agent in non-aged and aged samples was statistically analyzed by BCA method and MANOVA. The effects of the extraction agents on the protein structure were characterized. It could be concluded that:

For both non-aged and aged samples, the extraction efficiency of $2 \mathrm{M} \mathrm{GuHCl}$ was significantly higher than the other five extracting agents. For different types of nonaged samples, there is no evident difference in the extraction efficiency using the same extraction agents.

As aging time increased, the extraction efficiency of all agents decreased significantly, but more distinctive from control except for urea.

All the agents caused a certain degree of damage to the $\mathrm{C}=\mathrm{O},-\mathrm{COOH}$, and $-\mathrm{CONH}_{2}$ groups in the polypeptide chain, and slightly deconstructed the triple helix structure of the extracted protein. Among them, 0.1\%
TFA, $0.5 \mathrm{M}$ Acetic acid and $2 \mathrm{M} \mathrm{GuHCl}$ had relatively less influence on protein microstructure. Except for $2 \mathrm{M}$ ammonia, the other five agents had no significant impact on the purity and molecular weight of the protein.

$2 \mathrm{M} \mathrm{GuHCl}$ has the potential to serve as a more suitable extraction agent, as it is more promising in the preservation and recovery of more genuine proteinaceous residues for accurate identification.

\section{Appendix}

Components of some reagents used were as follows:

$1 \times$ PBS: Mix $0.01 \mathrm{M} \mathrm{NaH}_{2} \mathrm{PO}_{4}$ and $0.01 \mathrm{M} \mathrm{Na}_{2} \mathrm{HPO}_{4}$ at a volume ratio of 19:81 and adjust the $\mathrm{pH}$ to 7.4.

BCA reagent: Mix BCA disodium salt $(0.10 \mathrm{~g})$, anhydrous sodium carbonate $(2.00 \mathrm{~g})$, sodium tartrate $(0.16 \mathrm{~g})$, sodium hydroxide $(0.40 \mathrm{~g})$ and sodium bicarbonate $(0.95 \mathrm{~g})$, add deionized water to $100 \mathrm{~mL}$, adjust to the $\mathrm{pH}$ to 11.25 .

$\mathrm{Cu}$ reagent: Dissolve $\mathrm{CuSO}_{4} \cdot 5 \mathrm{H}_{2} \mathrm{O}(0.4 \mathrm{~g})$ in $10 \mathrm{~mL}$ deionized water.

Coomassie Brilliant Blue G-250 Staining solution: Mix $0.1 \mathrm{~g}$ of Coomassie Brilliant Blue G-250 with $50 \mathrm{~mL} \mathrm{95 \%}$ ethanol and $120 \mathrm{~mL} 85 \%$ phosphoric acid, add deionized water to make the volume to $1000 \mathrm{~mL}$.

Destaining solution: Mix methanol, glacial acetic acid and deionized water at a volume ratio of 3:1:6.

7\% resolving gel: Mix $2.3 \mathrm{~mL} 30 \%$ acrylamide solution, $2.5 \mathrm{~mL} 1.5 \mathrm{M}$ Tris- $\mathrm{HCl}(\mathrm{pH} 8.8)$ solution, $100 \mu \mathrm{L} 10 \%$ SDS solution, $100 \mu \mathrm{L} 10 \%$ ammonium persulfate solution and $10 \mu \mathrm{L}$ TEMED, add deionized water to the total volume of $10 \mathrm{~mL}$.

5\% stacking gel: Mix $0.83 \mathrm{~mL} 30 \%$ acrylamide solution, $0.625 \mathrm{~mL} 1 \mathrm{M}$ Tris- $\mathrm{HCl}$ (pH 6.8) solution, $50 \mu \mathrm{L} 10 \%$ SDS solution, $75 \mu \mathrm{L} 10 \%$ ammonium persulfate solution and $7.5 \mu \mathrm{L}$ TEMED, add deionized water to the total volume of $5 \mathrm{~mL}$.

\section{Supplementary Information}

The online version contains supplementary material available at https://doi. org/10.1186/s40494-021-00519-y.

Additional file 1: Table S1. Results of MANOVA on the effects of extraction agent and animal glue type on extraction efficiency. Table S2. Results of MANOVA on the effects of extraction agent type and aging time on extraction efficiency. Table S3. Results of MANOVA only for three groups of samples aged $1000 \mathrm{~h}, 1500 \mathrm{~h}$ and $2000 \mathrm{~h}$

\section{Acknowledgements}

Not applicable.

\section{Authors' contributions}

JD: Methodology, validation, investigation, data analyses, writing —original draft, writing - review and editing. ZZ: methodology, validation, investigation, 
writing —original draft, writing — review and editing, project administration. JY: methodology, project administration. JW: investigation, data analyses. XJ: writing - review and editing. All authors read and approved the final manuscript.

\section{Funding}

This work was supported by The National Social Science Fund of China (Project No. 19CKG025).

\section{Availability of data and materials}

The data and materials used during the study are available from the corresponding author on reasonable requests.

\section{Declarations}

\section{Competing interests}

The authors declare that they have no competing interests.

\section{Author details}

${ }^{1}$ Center for Nano Energy Materials, State Key Laboratory of Solidification Processing, School of Materials Science and Engineering, Northwestern Polytechnical University, Xi'an 710072, China. ${ }^{2}$ Conservation Science Laboratory, Department of History, College of Humanities, Xiamen University, Xiamen 361005, China. ${ }^{3}$ Institute of Culture and Heritage, Northwestern Polytechnical University, Xi'an 710072, China.

Received: 10 December 2020 Accepted: 12 April 2021 Published online: 23 April 2021

\section{References}

1. Zhu Z, Eckfeld T. The development of conservation practices in China from the 1980s to the present. AICCM Bull. 2016;37:26-34.

2. Liu L, He J, Ye M, Zhu Z, Yang J. Spectral characterization of pigment from the No. 1 Cave, Kizil Cave-Temple Complex. J Spectrosc. 2019;2019:1-9.

3. Granzotto C, Arslanoglu J. Revealing the binding medium of a Roman Egyptian painted mummy shroud. J Cult Herit. 2017;27:170-4.

4. Ma Z, Yan J, Zhao X, Wang L, Yang L. Multi-analytical study of the suspected binding medium residues of wall paintings excavated in Tang tomb, China. J Cult Herit. 2017;24:171-4.

5. Fremout W, Dhaenens M, Saverwyns S, Sanyova J, Vandenabeele P, Deforce D, Moens L. Tryptic peptide analysis of protein binders in works of art by liquid chromatography-tandem mass spectrometry. Anal Chim Acta. 2010;658:156-62.

6. Zhang T, Ding M, Zhang H, Tao N, Wang X, Zhong J. Fish oil-loaded emulsions stabilized by synergetic or competitive adsorption of gelatin and surfactants on oil/water interfaces. Food Chem. 2019;308:125597.

7. Ding M, Zhang T, Zhang H, Tao N, Wang X, Zhong J. Gelatin molecular structures affect behaviors of fish oil-loaded traditional and pickering emulsions. Food Chem. 2019;309:125642.

8. Ding M, Zhang T, Zhang H, Tao N, Wang X, Zhong J. Gelatin-stabilized traditional emulsions: emulsion forms, droplets, and storage stability. Food Sci Hum Wellness. 2020;9:320-7.

9. Yamada S, Yamamoto K, Ikeda T, Yanagiguchi K, Hayashi Y. Potency of fish collagen as a scaffold for regenerative medicine. Biomed Res Int. 2014;2014:302932.

10. Ferraro V, Gaillard-Martinie B, Sayd T, Chambon C, Anton M, Santé-Lhoutellier V. Collagen type I from bovine bone. Effect of animal age, bone anatomy and drying methodology on extraction yield, self-assembly, thermal behaviour and electrokinetic potential. Int J BiolMacromol. 2017;97:55-66.

11. Zhu Z, Yu C, Luo W, Miao Y, Lu Z, Liu L, Yang J. Accurate identification of the pastry contained in a ceramic pot excavated from Jurou Li's grave from the Jin dynasty (1115-1234 ce) in Xi'an, Shaanxi, China. Archaeometry. 2020;62:130-40.

12. Zhu Z, Tan P, Yang J, Ge H, Liu L. Mass spectrometric identification of adhesive utilized in a Tian-tsui Tiara of the mid-Qing Dynasty (1776-1839 CE) in the collection of the Tang Clan Folk Museum. Stud Conserv. 2019;64:187-92.
13. Zhu Z, Yu C, Miao Y, Lu Z, Yang J. Mass spectrometry identification of the liquor contained in the plum vase excavated from Jurou Li's Grave of the Jin Dynasty (1115-1234 CE) in Xi'an, Shannxi, China. Herit Sci. 2018;6:45.

14. Tokarski C, Martin E, Rolando C, Cren-Olivé C. Identification of proteins in renaissance paintings by proteomics. Anal Chem. 2006;78:1494-502.

15. Rao H, Yang Y, Abuduresule I, Li W, Hu X, Wang C. Proteomic identification of adhesive on a bone sculpture-inlaid wooden artifact from the Xiaohe Cemetery, Xinjiang, China. J Archaeol Sci. 2015;53:148-55.

16. Zhu Z, Chen H-F, Li L, Gong D-C, Gao X, Yang J, Zhao X, Ji K. Biomass spectrometry identification of the fibre material in the pall imprint excavated from grave M1, Peng-state cemetery, Shanxi, China. Archaeometry. 2014;56:681-8.

17. Ren F, Atlasevich N, Baade B, Loike J, Arslanoglu J. Influence of pigments and protein aging on protein identification in historically representative casein-based paints using enzyme-linked immunosorbent assay. Anal Bioanal Chem. 2016:408:203-15.

18. Wu M, Zhang B, Yang J. Detection of millennial rosin in Empress Xiao's Crown by ELISA. Microchem J. 2020;154:104581.

19. Hu W, Zhang K, Zhang H, Zhang B, Rong B. Analysis of polychromy binder on Qin Shihuang's Terracotta Warriors by immunofluorescence microscopy. J Cult Herit. 2015;16:244-8.

20. Gautier G, Colombini MP. GC-MS identification of proteins in wall painting samples: a fast clean-up procedure to remove copper-based pigment interferences. Talanta. 2007;73:95-102.

21. Tomasini E, Rodríguez DC, Gómez BA, de Faria DLA, Landa CR, Siracusano G, Maier MS. A multi-analytical investigation of the materials and painting technique of a wall painting from the church of Copacabana de Andamarca (Bolivia). Microchem J. 2016;128:172-80.

22. Yan H, An J, Zhou T, Li Y. Analysis of proteinaceous binding media used in Tang Dynasty polychrome pottery by MALDI-TOF-MS. Chin Sci Bull. 2013;58:2932-7.

23. Kuckova S, Sandu ICA, Crhova M, Hynek R, Fogas I, Muralha VS, Sandu AV. Complementary cross-section based protocol of investigation of polychrome samples of a 16th century Moravian Sculpture by optical, vibrational and mass spectrometric techniques. Microchem J. 2013;110:538-44.

24. Tripković T, Charvy C, Alves S, Lolić AĐ, Baošić RM, Nikolić-Mandić SD, Tabet JC. Identification of protein binders in artworks by MALDI-TOF/TOF tandem mass spectrometry. Talanta. 2013;113:49-61.

25. Orsini S, Yadav A, Dilillo M, McDonnell LA, Bonaduce I. Characterization of degraded proteins in paintings using bottom-up proteomic approaches: new strategies for protein digestion and analysis of data. Anal Chem. 2018;90:6403-8.

26. Vinciguerra R, De Chiaro A, Pucci P, Marino G, Birolo L. Proteomic strategies for cultural heritage: from bones to paintings. Microchem $\mathrm{J}$. 2016;126:341-8.

27. Mackie M, Rüther P, Samodova D, Di Gianvincenzo F, Granzotto C, Lyon D, Peggie D, Howard H, Harrison L, Jensen L, Olsen J, Cappellini E. Palaeoproteomic profiling of conservation layers on a 14th century Italian wall painting. Angew Chem Int Ed. 2018;57:7369.

28. Leo G, Cartechini L, Pucci P, Sgamellotti A, Marino G, Birolo L. Proteomic strategies for the identification of proteinaceous binders in paintings. Anal Bioanal Chem. 2009:395:2269-80.

29. Levy IK, Neme Tauil R, Valacco MP, Moreno S, Siracusano G, Maier MS. Investigation of proteins in samples of a mid-18th century colonial mural painting by MALDI-TOF/MS and LC-ESI/MS (Orbitrap). Microchem J. 2018;143:457-66.

30. Chambery A, Di Maro A, Sanges C, Severino V, Tarantino M, Lamberti A, Parente A, Arcari P. Improved procedure for protein binder analysis in mural painting by LC-ESI/Q-q-TOF mass spectrometry: detection of different milk species by casein proteotypic peptides. Anal Bioanal Chem. 2009;395:2281-91.

31. Fremout W, Kuckova S, Crhova M, Sanyova J, Saverwyns S, Hynek R, Kodicek M, Vandenabeele P, Moens L. Classification of protein binders in artist's paints by matrix-assisted laser desorption/ionisation time-of-flight mass spectrometry: an evaluation of principal component analysis (PCA) and soft independent modelling of class analogy (SIMCA). Rapid Commun Mass Spectrom. 2011;25:1631-40.

32. Bleicher N, Kelstrup C, Olsen JV, Cappellini E. Molecular evidence of use of hide glue in 4th millennium BC Europe. J Archaeol Sci. 2015;63:65-71. 
33. Pal GK, Suresh PV. Comparative assessment of physico-chemical characteristics and fibril formation capacity of thermostable carp scales collagen. Mater Sci Eng, C. 2017;70:32-40.

34. Bhuimbar MV, Bhagwat PK, Dandge PB. Extraction and characterization of acid soluble collagen from fish waste: development of collagen-chitosan blend as food packaging film. J Environ Chem Eng. 2019;7:102983.

35. Nielsen-Marsh CM, Hedges REM, Mann T, Collins MJ. A preliminary investigation of the application of differential scanning calorimetry to the study of collagen degradation in archaeological bone. Thermochim Acta. 2000;365:129-39.

36. Buckley M, Whitcher Kansa S, Howard S, Campbell S, Thomas-Oates J, Collins M. Distinguishing between archaeological sheep and goat bones using a single collagen peptide. J Archaeol Sci. 2010;37:13-20.

37. Kheirabadi EK, Razavi SH, Khodaiyan F, Golmakani M-T. Optimizing the extraction of acid-soluble collagen inside the eggshell membrane. Food SciTechnol Res. 2018;24:385-94.

38. Dallongeville S, Koperska M, Garnier N, Reille-Taillefert G, Rolando C, Tokarski C. Identification of animal glue species in artworks using proteomics: application to a 18th century gilt sample. Anal Chem. 2011;83:9431-7.

39. Kirby DP, Buckley M, Promise E, Trauger SA, Holdcraft TR. Identification of collagen-based materials in cultural heritage. Analyst. 2013;138:4849-58.

40. Kuckova S, Sandu ICA, Crhova M, Hynek R, Fogas I, Schafer S. Protein identification and localization using mass spectrometry and staining tests in cross-sections of polychrome samples. J Cult Herit. 2013;14:31-7.

41. Fremout $W$, Dhaenens M, Saverwyns S, Sanyova J, Vandenabeele $P$, Deforce D, Moens L. Development of a dedicated peptide tandem mass spectral library for conservation science. Anal Chim Acta. 2012;728:39-48.

42. Barker A, Venables B, Stevens SM, Seeley KW, Wang P, Wolverton S. An optimized approach for protein residue extraction and identification from ceramics after cooking. J Archaeol Method Theory. 2012;19:407-39.

43. Klaas J, Berg I, Bonaduce E, Ferreira K, Sutherland D, Peggie C, Maines, Mazurek J, Svoboda M, Maish J, Kawahara K, Fukakusa S, Nakazawa T, Taniguchi Y. Characterization of binding media in Egyptian romano portraits using enzyme-linked immunosorbant assay and mass spectrometry. E-PreservSci. 2014;11:76-83.

44. Magrini D, Bracci S, Sandu I. Fluorescence of organic binders in painting cross-sections. Procedia Chem. 2013;8:194-201.

45. Kumazawa Y, Taga Y, Takashima M, Hattori S. A novel LC-MS method using collagen marker peptides for species identification of glue applicable to samples with multiple animal origins. HeritSci. 2018;6:43.

46. Kouloumpi E, Vandenabeele P, Lawson G, Pavlidis V, Moens L. Analysis of post-byzantine icons from the church of the assumption in cephalonia, Ionian Islands, Greece: a multi-method approach. Anal Chim Acta. 2007;598:169-79.

47. Poli T, Piccirillo A, Zoccali A, Conti C, Nervo M, Chiantore O. The role of zinc white pigment on the degradation of shellac resin in artworks. Polym Degrad Stab. 2014;102:138-44.

48. Romero-Pastor J, Cardell C, Yebra-Rodríguez Á, Rodríguez-Navarro AB. Validating chemical and structural changes in painting materials by principal component analysis of spectroscopic data using internal mineral standards. J Cult Herit. 2013;14:509-14.

49. He L, Wang N, Zhao X, Zhou T, Xia Y, Liang J, Rong B. Polychromic structures and pigments in Guangyuan Thousand-Buddha Grotto of the Tang Dynasty (China). J ArchaeolEnce. 2012;39:1809-20.

50. Mazzocchin GA, Agnoli F, Mazzocchin S, Colpo I. Analysis of pigments from Roman wall paintings found in Vicenza. Talanta. 2003;61:565-72.

51. Budrugeac P, Cucos A. Application of Kissinger, isoconversional and multivariate non-linear regression methods for evaluation of the mechanism and kinetic parameters of phase transitions of type I collagen. Thermochim Acta. 2013;565:241-52.

52. Chandra MV, Shamasundar BA. Rheological properties of gelatin prepared from the swim bladders of freshwater fish Catlacatla. Food Hydrocoll. 2015;48:47-54.

53. Selli E, Beltrame PL, Testa G, Bonfatti AM, Rossi E, Seves A. Kinetic studies on the accelerated aging of cellulosic materials. Die Angewandte Makromolekulare Chemie. 1998;257:63-9.

54. Robinson ID. Rate of crosslinking of gelatin in aqueous solution. J Appl Polym Sci. 1964;8:1903-18.

55. Croome RJ. Acid and alkaline hydrolysis of gelatin. J Appl Chem. 1953;3:280-6.
56. Smith PK, Krohn RI, Hermanson GT, Mallia AK, Gartner FH, Provenzano MD, Fujimoto EK, Goeke NM, Olson BJ, Klenk DC. Measurement of protein using bicinchoninic acid. Anal Biochem. 1985;150:76-85.

57. Laemmli UK. Cleavage of structural proteins during the assembly of the head of bacteriophage T4. Nature. 1970;227:680-5.

58. Duhamel RC, Meezan E, Brendel K. The addition of SDS to the Bradford dye-binding protein assay, a modification with increased sensitivity to collagen. J Biochem Biophys Methods. 1981;5:67-74.

59. López J, Imperial S, Valderrama R, Navarro S. An improved bradford protein assay for collagen proteins. ClinChimActa. 1993;220:0-100.

60. Gazzola D, Vincenzi S, Pasini G, Lomolino G, Curioni A. Advantages of the KDS/BCA assay over the bradford assay for protein quantification in white wine and grape juice. Am J Enol Vitic. 2015;66:227-33.

61. Cortés-Ríos J, Zárate A, Figueoa-Alegria J, Medina J, Fuentes-Lemus E, Rodríguez-Fernández M, Aliaga M, López-Alarcón C. Protein quantification by bicinchoninic acid (BCA) assay follows complex kinetics and can be performed at short incubation times. Anal Biochem. 2020;608:113904

62. Caradec J, Kharmate G, Hosseini-Beheshti E, Adomat H, Gleave M, Guns E. Reproducibility and efficiency of serum-derived exosome extraction methods. Clin Biochem. 2014;47:1286-92.

63. Albillos SM, Al-Taher F, Maks N. Increasing extractability of protein for allergen detection after food processing. Food Chem. 2011;127:1831-4.

64. Krieg RC, Dong Y, Schwamborn K, Knuechel R. Protein quantification and its tolerance for different interfering reagents using the BCA-method with regard to 2D SDS-PAGE. J Biochem Biophys Methods. 2005;65:13-9.

65. Smith PK, Krohn RI, Hermanson GT, Mall AK, Klenk DC. Measurement of protein using BCA. Anal Biochem. 1985;150:76-185.

66. Brenner AJ, Harris ED. A quantitative test for copper using bicinchoninic acid. Anal Biochem. 1995;226:80-4.

67. Walker JM. The bicinchoninic acid (BCA) assay for protein quantitation. Methods Mol Biol. 1994;32:5-8.

68. Ding M, Zhang T, Zhang H, Tao N, Wang X, Zhong J. Effect of preparation factors and storage temperature on fish oil-loaded crosslinked gelatin nanoparticle pickering emulsions in liquid forms. Food Hydrocoll. 2019:95:326-35.

69. Duce C, Bramanti E, Ghezzi L, Bernazzani L, Bonaduce I, Colombini MP, Spepi A, Biagi S, Tine MR. Interactions between inorganic pigments and proteinaceous binders in reference paint reconstructions. Dalton Trans (Camb, Engl: 2003). 2013;42:5975-84.

70. Ghezzi L, Duce C, Bernazzani L, Bramanti E, Colombini MP, Tiné MR, Bonaduce I. Interactions between inorganic pigments and rabbit skin glue in reference paint reconstructions. J Therm Anal Calorim. 2015;122:315-22.

71. Cassel J. Collagen aggregation phenomena. Biopolymers. 1966;4:989-97.

72. Liu WG, Yao KD, Wang GC, Li HX. Intrinsic fluorescence investigation on the change in conformation of cross-linked gelatin gel during volume phase transition. Polymer. 2000;41:7589-92.

73. Karpowicz A. Ageing and deterioration of proteinaceous media. Stud Conserv. 1981;26:153-60.

74. Sgarbossa A, Monti S, Lenci F, Bramanti E, Bizzarri R, Barone V. The effects of ferulic acid on $\beta$-amyloid fibrillar structures investigated through experimental and computational techniques. BiochimBiophysActa Gen Subj. 2013;1830:2924-37.

75. Shang S, Zhu L, Fan J. Intermolecular interactions between natural polysaccharides and silk fibroin protein. Carbohyd Polym. 2013;93:561-73.

76. Orsini S, Parlanti F, Bonaduce I. Analytical pyrolysis of proteins in samples from artistic and archaeological objects. J Anal Appl Pyrol. 2017;124:643-57.

77. Kamoun P. Denaturation of globular proteins by urea: breakdown D of hydrogen or hydrophobic bonds. Trends Biochem Sci. 1988;13:424-5.

78. Frank H, Franks F. Structural approach to the solvent power of water for hydrocarbons; Urea as a structure breaker. J Chem Phys. 1968;48:4746-57.

79. Rezus Y, Bakker H. Effect of urea on the structural dynamics of water. Proc Natl Acad Sci USA. 2007;103:18417-20.

80. Nicolai T, Durand D. Controlled food protein aggregation for new functionality. Curr Opin Colloid Interface Sci. 2013;18:249-56.

81. Shang S, Zhu L, Fan J. Intermolecular interaction between natural polysaccharides and silk fibroin protein. Carbohyd Polym. 2013;93:561-73.

82. Monera O, Kay C, Hodges R. Protein denaturation with guanidine hydrochloride or urea provides a different estimate of stability depending on the contributions of electrostatic interactions. Protein Sci. 1994;3:1984-91. 
83. Zhang T, Ding M, Tao L, Liu L, Tao N, Wang X, Zhong J. Octenyl succinic anhydride modification of bovine bone and fish skin gelatins and their application for fish oil-loaded emulsions. Food Hydrocoll. 2020;108:106041.

84. Zhang T, Xu J, Zhang Y, Wang X, Lorenzo JM, Zhong J. Gelatins as emulsifiers for oil-in-water emulsions: extraction, chemical composition, molecular structure, and molecular modification. Trends Food Sci Technol. 2020;106:113-31.

85. Chen J, Li L, Yi R, Xu N, Gao R, Hong B. Extraction and characterization of acid-soluble collagen from scales and skin of tilapia (Oreochromis niloticus). LWT Food Sci Technol. 2016;66:453-9.

86. Staicu T, Circu V, Ionita G, Ghica C, Popa V, Micutz M. Analysis of bimodal thermally-induced denaturation of type I collagen extracted from calfskin. RSC Adv. 2015;5:38391-406.

87. Kigawa R, Strang T, Hayakawa N, Yoshida N, Kimura H, Young G. Investigation of effects of fumigants on proteinaceous components of museum objects (muscle, animal glue and silk) in comparison with other nonchemical pest eradicating measures. Stud Conserv. 2011:56:191-215.

88. Veeruraj A, Arumugam M, Balasubramanian T. Isolation and characterization of thermostable collagen from the marine eel-fish (Evenchelys macrura). Process Biochem. 2013;48:1592-602.
89. Chen S, Chen H, Xie Q, Hong B, Chen J, Hua F, Bai K, He J, Yi R, Wu H. Rapid isolation of high purity pepsin-soluble type I collagen from scales of red drum fish (Sciaenops ocellatus). Food Hydrocoll. 2016;52:468-77.

90. Huang $\mathrm{Y}-\mathrm{R}$, Shiau $\mathrm{C}-\mathrm{Y}$, Chen H-H, Huang B-C. Isolation and characterization of acid and pepsin-solubilized collagens from the skin of balloon fish (Diodonholocanthus). Food Hydrocoll. 2011;25:1507-13.

91. Zhang Z, Liu W, Dong LI, Guoying LI. Physicochemical properties of succinylated calfskin pepsin-solubilized collagen. J Agric Chem Soc Jpn. 2007;71:4.

92. Lopes JLS, Miles AJ, Whitmore L, Wallace BA. Distinct circular dichroism spectroscopic signatures of polyproline II and unordered secondary structures: applications in secondary structure analyses. Protein Sci. 2014;23:1765-72.

\section{Publisher's Note}

Springer Nature remains neutral with regard to jurisdictional claims in published maps and institutional affiliations.

\section{Submit your manuscript to a SpringerOpen ${ }^{\circ}$ journal and benefit from:}

- Convenient online submission

- Rigorous peer review

- Open access: articles freely available online

- High visibility within the field

- Retaining the copyright to your article

Submit your next manuscript at $\boldsymbol{\nabla}$ springeropen.com 